\title{
Effect of SCD SNPs on milk production traits of Jersey cows (Brief Report)
}

\author{
Auswirkungen der SCD SNPs auf die Milchleistungmerkmale \\ bei Jersey Kühen (Brief Report)
}

\author{
HANNA KULIG, INGA KOWALEWSKA-ŁUCZAK and MAREK KMIEĆ \\ Department of Genetics and Animal Breeding, Westpomeranian University of Technology, Szczecin, Poland
}

\section{Background}

Studies concerning associations between candidate gene polymorphisms and milk production traits in cattle are carried out on a large scale (CITEK et al. 2007, KULIG 2005). Stearoyl-CoA desaturase (SCD) is the enzyme involved in conversion of saturated fatty acids into monounsaturated fatty acids. The gene encoding SCD was mapped to bovine chromosome 26 (CAMPBELL et al. 2001), where some QTLs for fat yield and other milk production traits as well as for somatic cells count (SCC) were also identified. Some of the SNPs identified within the $S C D$ were significantly associated with fatty acid composition in milk and in carcass fat tissue (MOIOLI et al. 2007, TANIGUCHI et al. 2004). The effect of genotypes on milk production traits and SCC in cattle has not been reported so far. The aim of this study was therefore to establish possible associations between two SNPs in the SCD and milk production traits and SCC in Jersey cows.

\section{Procedure}

The analysed polymorphic sites localised in exon 3 of the $S C D$ gene were as follows: $G / A$ and $C / T$ transitions in positions 10153 and 10329, respectively (GeneBank acc. no. AY241932). The latter SNP results in an alanine-to-valine substitution in the polypeptide sequence. The $S C D$ genotypes were identified according to TANIGUCHI et al. (2004).

Primer sequences

SCD10153-F

5'-GTG TCC TGT TGT TGT GCT TCA TCC TGC C-3'

SCD10153-R

5'-AAT ATT CTC TCG GGG GTT GAT GGT CTT G-3'

SCD10329-F

5'-ATG TAT GGA TAC CGC CCT TAT GAC-3'

SCD10329-R

5'-TTC TGG CAC GTA ACC TAA TAC CCT AAG C-3'

Next, a statistical analysis of associations between the SNPs and milk traits (milk yield, kg; fat content, \%; protein content, $\%$ and SCC, In) was performed. A total of 1315 test-day observations for the above traits were obtained monthly from 180 Jersey cows belonging to one herd. The analysis was carried out using the GLM (STATISTICA 2006); the genotype, number of consecutive lactation (1-5), season of lactation (1-4), month of lactation (1-14), cow as a random factor nested within genotype (1-180) were defined in a linear model. 


\section{Results}

In the studied herd of Jersey cows, all the possible SCD genotypes were identified. The most frequent alleles for each SNP were as follows: $A-0.76$ for $10153 G / A$ and $C-0.74$ for $10329 C / T$. Seven out of nine possible combined genotypes were found, the three most frequent being $A A-C C-0.47, G A-T C-0.38$ and $A A-T C-0.08$. As regards the physiological function and/or chromosomal localisation, the $S C D$ might be considered as a candidate gene for milk fat traits. Unfortunately, no associations were found between the studied polymorphisms and fat content in milk of the studied cows (data not shown). Similarly, in terms of milk yield and protein content, the differences between the respective SCD genotypes were statistically non-significant . Although, the study results show statistically significant differences in the mean SCC values in cows with different $10329 \mathrm{C} / T$ genotypes (Table 1). The TT cows were characterised by a significantly $(P \leq 0.01)$ higher In SCC in milk compared with the CC and TC cows. The difference between the TT and CC individuals averaged 0.528395 while the difference between the TT and TC cows was lower (0.450844). As regards the $10153 \mathrm{G} / \mathrm{A}$ polymorphism, no significant differences were found in this study between the genotypes and SCC. Moreover, an analysis of the combined genotype data showed no statistically significant differences among cows with different genotypes in relation to the trait under study.

Table 1

Means and standard deviations of SCC in cows with different SCD genotypes

Mittelwerte und Standardabweichungen der SCC bei Kühen mit verschiedenen SCD-Genotypen

\begin{tabular}{lcrc}
\hline Polymorphism & Genotype & $\mathrm{N}$ & $\ln \mathrm{SCC}$ \\
\hline \multirow{3}{*}{$10153 \mathrm{G} / \mathrm{A}$} & $A A$ & 1315 & $5.192585 \pm 1.145354$ \\
& $G A$ & 1119 & $5.196667 \pm 1.191726$ \\
$10329 \mathrm{C} / \mathrm{T}$ & $\mathrm{GG}$ & 111 & $5.439986 \pm 1.144766$ \\
& $C C$ & 1217 & $5.148583 \pm 1.116710^{\mathrm{A}}$ \\
& $T C$ & 1237 & $5.226134 \pm 1.195735^{\mathrm{B}}$ \\
& $T T$ & 91 & $5.676978 \pm 1.307258^{\mathrm{AB}}$ \\
$10153 G / A-10329 C / T$ & 1123 & $5.155977 \pm 1.111552$ \\
& $A A-C C$ & 192 & $5.406706 \pm 1.308770$ \\
& $A A-T C$ & 94 & $5.060250 \pm 1.179212$ \\
& $G A-C C$ & 1001 & $5.182552 \pm 1.179711$ \\
& $G A-T C$ & 24 & $6.319666 \pm 1.225492$ \\
& $G A-T T$ & 44 & $5.429670 \pm 0.944374$ \\
& $G G-T C$ & 67 & $5.446761 \pm 1.266089$ \\
\hline
\end{tabular}

$\mathrm{N}$ number of test-day records. The means in columns marked with the same superscript letter differ significantly at $P \leq 0.01$.

The presented results suggest that the $S C D-10329 C / T$ genotypes might contribute to a decreased SCC in Jersey cattle; cows with $C$ allele should be preferred in selection programmes. Therefore, the SCD could be proposed as a candidate gene for SCC. Nevertheless, further studies will be necessary to confirm the result. 


\section{References}

Campbell EMG, Gallagher DS, Davis SK, Taylor JF, Smith SB (2001) Rapid communication: Mapping of the bovine stearoyl-coenzyme A desaturase (SCD) gene to BTA26. J Anim Sci 79, 1954-5

Citek J, Rehout V, Hradecka E, Vecerek L, Panicke L (2007) The breeding values of German Holstein sires and the DGAT1 polymorphism. Arch Tierz 50, 136-46

Kulig H (2005) Association between leptin combined genotypes and milk performance traits of Polish Black-and-White cows. Arch Tierz 48, 547-54

Moioli B, Contarini G, Avalli A, Catillo G, Orrù L, De Matteis G, Masoero G, Napolitano F (2007) Short communication: Effect of stearoyl-CoA desaturase polymorphism on fatty acid composition of milk. J Dairy Sci 90, 3553-8

Taniguchi M, Utsugi T, Oyama K, Mannen H, Kobayashi M, Tanabe Y, Ogino A, Tsuji S (2005) Genotype of stearoyl-CoA desaturase is associated with fatty acid composition in Japanese Black cattle. Mamm Genome 14, 142-8

Received 8 April 2009, accepted 16 November 2009.

Corresponding author:

HANNA KULIG

email: hanna.kulig@zut.edu.pl

Department of Genetics and Animal Breeding, Westpomeranian University of Technology, Doktora Judyma 6, 71-466 Szczecin, Poland 